\title{
Preemptive analgesia of metamizole versus ibuprofen in retinal laser photocoagulation
}

\author{
Analgesia preemptiva com dipirona versus \\ ibuprofeno na fotocoagulação a laser da retina
}

Artur Macaferri Del Santo1, Renato Maluf Auge1, Caroline Amaral Ferraz ${ }^{2}$

\begin{abstract}
Objective: To compare the effectiveness of metamizole versus ibuprofen for the reduction of pain in retinal photocoagulation (RP). Method: A double-masked randomized controlled study was performed. Thirty-four patients with diabetic retinopathy were enrolled. The patients were randomized into two groups. Group A received oral $1000 \mathrm{mg}$ metamizole. Group B received an oral intake of $600 \mathrm{mg}$ ibuprofen. Pain during RP was assessed using a visual analog scale. Results: The mean pain scores for groups $A$ and $B$ were $5.2 \pm 2.6$ and $4.5 \pm 1.4(p=0.34)$. There were no significant differences in the mean pain scores between the two groups. The same is observed when analyzing by low, medium and high pain $(p=0.09)$. The groups were similar in age and gender. Conclusion: Both drugs were equivalents or equipotent in reduce ocular pain during retinal photocoagulation.
\end{abstract}

Keywords: Retinal laser photocoagulation; Pain; Analgesia; Retinopathy; Metamizole; Ibuprofen

\section{RESUMO}

Objetivo: Comparar a efetividade da dipirona versus o ibuprofeno para a redução da dor na fotocoagulação da retina (FR). Método: Foi realizado um estudo controlado, duplo cego e randomizado englobando trinta e quatro pacientes com retinopatia diabética separados em dois grupos. Grupo A recebeu 1000mg de dipirona e o grupo B recebeu 600mg de ibuprofeno. A dor foi avaliada pela escala visual analógica. Resultado: A média do escore da dor nos grupos A e B foi de 5,2 \pm 2.6 e 4,5 $\pm 1,4$, respectivamente. Não houve diferença estatística entre os grupos $(p=0,34)$. O mesmo foi observado quanto à analise entre dor leve, moderada e grave $(\mathrm{p}=0,09)$. Os grupos foram semelhantes quanto à idade e sexo. Conclusão: Os medicamentos foram equivalentes ou equipotentes em reduzir a dor ocular durante a fotocoagulação a laser da retina.

Descritores: Analgesia; Fotocoagulação a laser; Dor; Retinopatia; Dipirona; Ibuprofeno

${ }^{1}$ Course of Study of Medicine, Universidade Anhembi Morumbi, São Paulo, SP, Brazil.

${ }^{2}$ Department of Ophthalmology, Universidade Anhembi Morumbi, São Paulo, SP, Brazil.

The authors declare no conflicts of interests.

Received for publication 17/08/2015 - Accepted for publication 29/09/2015

Rev Bras Oftalmol. 2016; 75 (1): 14-7 


\section{INTRODUCTION}

$\mathbf{P}$ ain is an unpleasant sensory and emotional experience associated to actual or potential tissue damage.

The preemptive analgesy uses the concept that neuronal excitation can be eliminated if the afferent signal is interrupted or reduced to reach the central nervous system, either by local anesthetic blockage or other analgesics before receiving the noxious stimulus ${ }^{(1)}$.

Many studies have shown that most patients experience some degree of pain during laser panphotocoagulation of the retina, even after the use of anesthetic eyedrops ${ }^{(2,3)}$. The pain ranges from mild to severe, and may in some cases be intolerable, becoming necessary to use general anesthesia or anesthetic block. Both procedures increase the risk of future morbidity and even mortality ${ }^{(4)}$.

Some works tried to demonstrate the significant reduction of pain with the use of various methods, since paracetamol, acupuncture to general anesthesia ${ }^{(1,3,4)}$, and the use of analgesics in a preemptive way for said procedure is not established. It has not been found in the literature studies using metamizole, despite being widely used in our environment for reducing pain in general $^{(5,6)}$.

Several analgesics have been tested for reducing moderate acute ocular pain, and some, such as ibuprofen, have had satisfactory results, being the most used in the United States ${ }^{(7)}$.

Our goal is to compare the analgesic effect of metamizole versus ibuprofen during retinal photocoagulation for the treatment of diabetic retinopathy.

\section{Methods}

Clinical, prospective, double-blind, randomized study comparing the effect of metamizole versus ibuprofen as preemptive analgesy in patients with diabetic retinopathy subject to photocoagulation.

The study included: patients with proliferative diabetic retinopathy of both sexes diagnosed with diabetic retinopathy. The exclusion criteria were: infectious contagious disease, known allergic reaction to metamizole or ibuprofen, concomitant ocular pathology or any decompensated chronic pathology at the time of the procedure.

The data were collected during the period from November to April 2014 2015. Everyone who agreed to participate signed an informed consent.

The patients were randomly divided, and Group A was administered metamizole $1000 \mathrm{mg}$ and Group B ibuprofen 600 $\mathrm{mg}$. The medication was administered 30 to 45 minutes before the procedure.

To reduce corneal sensitivity prior to placing the contact lenses one droplet of proxymetacaine hydrochloride $0.5 \%$ sterile ophthalmic solution was administered. For pupil dilation, 3 droplets of tropicamide ophthalmic solution $10 \mathrm{mg} / \mathrm{ml}$ were used.

Immediately after the end of the procedure, the researchers assessed the pain felt during the laser procedure by means of a visual scale. The Visual Analogue Scale (VAS) for pain, a onedimensional, already established instrument for the assessment of pain intensity, was used for said assessment. It is a line with the ends numbered from 0 to 10 . At one end the line is marked "no pain" and the other "worst pain imaginable". Then, the patient is asked to assess and check the pain felt.

The research project was approved by the Research Ethics Committee at University Anhembi Morumbi, and those responsible for the patients who agreed to participate signed an Informed Consent.

Data were analyzed using statistical program SPSS version 20. The variables were expressed as mean and standard deviation for continuous variables and recorded as a percentage (categorical variables). All tests were two-tailed. The categorical variables were analyzed by the method 2, and the Fisher correction was used if needed. The continuous variables were assessed by Student's t-test.

\section{RESULTS}

34 patients, 21 men and 13 women, with diabetic retinopathy subjet to photocoagulation were analyzed. Each group comprised 17 patients (Group A - metamizole and Group B - ibuprofen). There was a significant age difference between sex, with men being older $55.7 \pm 12$ years versus $43.3 \pm 15$ years $(p=0.014)$ but not between treatment groups (Group A, average $50 \pm 15$ years versus Group B average $52 \pm 15$ years, $\mathrm{p}=0.64)$. There was no relation between sex and mean values in VAS score, $\mathrm{H}=4.8+2$ versus $\mathrm{M}=4.9+2.6(\mathrm{p}=0.9)$. As age was different between groups, it was investigated whether there was connection with the VAS score by means of linear regression without success $(r=0.023)$.

There were no differences in means between Groups A and $B$ to VAS scale, $A=5.2+2.6$ versus $4.5+1.4(p=0.34)$. This observation is maintained in the analysis by groups (mild, moderate, severe), $\mathrm{p}=0.09$ (Table 1 ).

Table 1

Type of pain and treatment group

\begin{tabular}{lrrrrr}
\hline $\begin{array}{l}\text { Degree } \\
\text { of pain }\end{array}$ & $\begin{array}{c}\text { Mild } \\
\mathbf{n}(\%)\end{array}$ & $\begin{array}{c}\text { Moderate } \\
\mathbf{n}(\%)\end{array}$ & $\begin{array}{c}\text { Severe } \\
\mathbf{n}(\%)\end{array}$ & Total \\
\hline Group & A & $6(35.3)$ & $5(29.4)$ & $6(35.3)$ & $17(100)$ \\
& B & $4(23.5)$ & $11(64.7)$ & $2(11.8)$ & $17(100)$ \\
\hline Total & & $\mathbf{1 0 ( 2 9 . 4 )}$ & $\mathbf{1 6 ( 4 7 . 1 )}$ & $\mathbf{8 ( 2 3 . 5 )}$ & $\mathbf{3 4 ( 1 0 0 )}$ \\
\hline
\end{tabular}

Group A (Metamizole) Group B (Ibuprofen)

Severe pain was separated from the other two degrees of pain (mild to moderate) with similar results, $\mathrm{p}=0.16$ (Table 2 ).

Table 2

Severe pain versus mild to moderate pain in both groups

\begin{tabular}{|c|c|c|c|}
\hline Severe pain & Absent n(\%) & Present n(\%) & Total n(\%) \\
\hline Group A & $11(64.7)$ & $6(35.3)$ & 17 (100) \\
\hline B & $15(88.2)$ & $2(11.8)$ & 17 (100) \\
\hline Total & $26(76.5)$ & $8(23.5)$ & 34 (100) \\
\hline
\end{tabular}

Group A (Metamizole) Group B (Ibuprofen)

We analyzed if the power of the shots could influence the presence of severe pain, Table 3. There was no significant difference $(\mathrm{p}=0.89)$. 
Table 3

Presence of severe pain and power of the shots

\begin{tabular}{lcrcc}
\hline & Severe Pain & N & Mean & SD \\
\hline \multirow{2}{*}{ Power } & Ausente & 26 & 184.62 & 75.484 \\
& Presente & 8 & 188.75 & 76.614 \\
\hline
\end{tabular}

$\mathrm{SD}=$ standard deviation

It was examined whether there was any influence between the two indexes constructed to observe if there was change by the technique used in both treatment groups. From being positive it could be inferred that the small variations between power and shots would influence the degree of pain, since the two drugs behaved as equivalent. However, there were no significant differences between the indexes and the preferred distribution between groups (Tables 4 and 5).

Table 4

Power / aim Index ( $\left.P \_A\right)$ in the groups studied

\begin{tabular}{ccccc}
\hline & Group & N & Mean & SD \\
\hline P_M & A & 17 & 0.9 & 0.319 \\
& B & 17 & 0.9 & 0.312 \\
\hline
\end{tabular}

$\mathrm{p}=0.95$

Table 5

Power / shot Index (P_S) in the groups studied

\begin{tabular}{lcccc}
\hline & Group & N & Mean & SD \\
\hline P_D & A & 17 & 2.13 & 6.9 \\
& B & 17 & 0.45 & 0.4 \\
\hline
\end{tabular}

$\mathrm{p}=0.32$

\section{Discussion}

Currently, it is estimated that 7 to $8 \%$ of the world's population is suffering from diabetes mellitus (DM). According to the World Health Organization, in 2010 the number of cases in the world has reached 347 million $^{(8)}$. Approximately $10 \%$ of the blind population in United States of America and the United Kingdom is a diabetic ${ }^{(9)}$.

The prevalence in Brazil is comparable to that of developed countries, where DM is considered the greatest health problem. In our country, it is among the 10 leading causes of mortality. However, it is in its morbidity that the greatest socio-economic impact is focused ${ }^{(10)}$. Diabetic retinopathy (DR) is the most specific vascular complication, both of DM type 1 and type 2 , and it is considered one of the diseases with the greatest potential to cause blindness ${ }^{(11,12)}$.

After 15 years of diabetes, the prevalence of retinopathy among patients with insulin-dependent diabetes mellitus is $97 \%$, and in non-insulin dependent diabetes is $80 \%{ }^{(9)}$.

The Diabetic Retinopathy Study (DRS) showed that the panphotocoagulation (PFC) of the retina is indicated for nonproliferative DR as severe and very severe for proliferative $\mathrm{DR}^{(13)}$. The ETDRS suggested that early treatment with laser reduces the risk of blindness in $50 \%^{(13,14)}$.
Other already pre-established conducts are also useful in the treatment of DR. Unfortunately, in many patients the retinopathy progresses even with the best conduct taken by the patient and by the ophthalmologist ${ }^{(15)}$.

Studies have shown that most patients demonstrate some degree of pain during and after a certain period of time of treatment ${ }^{(2,3,16)}$. The pain varies from moderate to severe, and may in some cases be intolerable, being necessary the use of general anesthesia or anesthetic block. Both procedures have proven effectiveness, but increase the risk of future morbidity and even mortality ${ }^{(4)}$.

The transcutaneous electrical stimulation have been reported as an effective and non-invasive way to reduce pain, but it requires specific equipment and refined setting, making it difficult to be used ${ }^{(16)}$.

It is still controversial the most effective analgesic method for controlling pain in the photocoagulation. NSAIDs can relieve pain by inhibiting the enzyme activity of cyclooxygenase and prostaglandin formation.

Diclofenac sodium $0.1 \%$ topic was effective in reducing pain during photocoagulation when compared to the placebo ${ }^{(17)}$. A Korean study showed that tramadol is not effective in eliminating pain, but it reduced severe pain compared to the placebo ${ }^{(18)}$. Another study has shown that the ophthalmic solution of ketorolac trometamol $0.5 \%$ was not different from artificial tears to reduce pain $^{(19)}$, as well as paracetamol compared to the placebo ${ }^{(10,13)}$.

In this study there was no statistical difference between the average of pain referred between the groups. The groups were similar in age and sex. The same result was produced by classifying the pain into mild (1-3), moderate (4-6) and severe (7-10). There was a tendency to feel severe pain with greater powers, but there is no significant difference, which can be justified by the sample size.

\section{Conclusion}

Both medications are equivalent or equinumerous in controlling the pain produced by photocoagulation.

\section{REFERENCES}

1. Vaideanu D, Taylor P, McAndrew P, Hildreth A, Deady JP, Steel $\mathrm{DH}$, et al. Double masked randomised controlled trial to assess the effectiveness of paracetamol in reducing pain in panretinal photocoagulation. Br J Ophthalmol. 2006; 90(6):713-7.

2. Al-Hussainy S, Dodson PM, Gibson JM. Pain response and followup of patients undergoing panretinal laser photocoagulation with reduced exposure times. Eye (Lond). 2008; 22(1):96-99.

3. Richardson C, Waterman H. Pain relief during panretinal photocoagulation for diabetic retinopathy: a national survey. Eye (Lond). 2009; 23(12):2233-7.

4. K Wu WC, Hsu KH, Chen TL, Hwang YS, Lin KK, Li LM, Lai CC. Interventions for relieving pain associated with panretinal photocoagulation: a prospective randomized trial. Eye (Lond). 2006; 20(6):712-9.

5. Danieli P, Leal MB. Avaliação da segurança da dipirona: uma revisão. Rev Bras Farm. 2003; 84(1):17-20.

6. Vale N. Desmistificando o uso da dipirona. In: Cavalcanti IL, Cantinho FA, Assad A. Medicina perioperatória. Rio de Janeiro: Editora da Sociedade de Anestesiologia do Estado do Rio de Janeiro; 2006; p.1107-24. 
7. Bartlett JB, Jaanus SD. Clinical Ocular Pharmacology. New York: Elsevier Health; 2008; p.100-7.

8. Danaei G, Finucane MM, Lu Y, Singh GM, Cowan MJ, Paciorek $\mathrm{CJ}$, et al. National, regional, and global trends in fasting plasma glucose and diabetes prevalence since 1980: systematic analysis of health examination surveys and epidemiological studies with 370 country-years and 2.7 million participants. Lancet. 2011; 378(9785):31-40.

9. Silva VB, Temporini ER, Moreira Filho DD, Kara-José N Tratamento da retinopatia diabética: percepções de pacientes em Rio Claro (SP)-Brasil. Arq Bras Oftalmol. 2005; 68(3):363-8.

10. Dias AF, Vieira MF, Rezende MP, Oshima A, Muller ME, dos Santos ME. Perfil epidemiológico e nível de conhecimento de pacientes diabéticos sobre Diabetes e retinopatia diabética. Arq Bras Oftalmol. 2010; 73(5):414-8.

11. Ávila M. A retina no século XXI. Arq Bras Oftalmol. 2003; 66(5):719-30.

12. Bosco A, Lerário AC, Soriano D, Santos RF, Massote P, Galvão D, Ferreira AR. Retinopatia diabética. Arq Bras Endocrinol Metabol. 2005;49 (2):217-27.

13. The Diabetic Retinopathy Study Research Group: Indications for photocoagulation treatment of diabetic retinopathy. Diabetic Retinopathy Study Report Number 14. Int Ophthalmol Clin. 1994; 27(4):239-53.

14. Maia Júnior OD, Marback RF, Bonanomi MT, Takahashi WY, Kara-José N. Avaliação oftalmológica tardia em portadores de retinopatia diabética. Rev Assoc Med Bras. 2007; 53(1):39-43.
15. Sabrosa NA, Sabrosa AS, Gouvea KC, Gonçalves Filho P. Surgical management of diabetic retinopathy. Rev Bras Oftalmol. 2013; 72(3):204-9.

16. Whitacre MM. The effect of transcutaneous electrical nerve stimulation on ocular pain. Ophthalmic Surg. 1991; 22(8): 462-6.

17. Nichols J, Snyder RW. Topical nonsteroidal anti-inflammatory agents in ophthalmology. Curr Opin Ophthalmol.1998;9(4):40-4.

18. Ko BW, Shim JH, Lee BR, Cho HY. Analgesic effects of tramadol during panretinal photocoagulation. Korean J Ophthalmol. 2009; 23(4):273-6.

19. Esgin H, Samut HS. Topical ketorolac $0.5 \%$ for ocular pain relief during scatter laser photocoagulation with $532 \mathrm{~nm}$ green laser. J Ocul Pharmacol Ther. 2006;22(6):460-4.

\section{Corresponding author:}

Renato Maluf Auge

Rua Dr. Almeida Lima, 1.134 - Mooca - ZIP Code: 03164-000

Fax: 011 - 30213991

E-mail: reauge@terra.com.br 